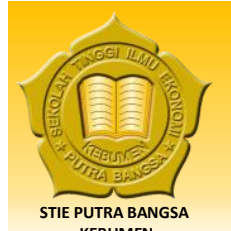

\title{
Analisis Pengaruh Online Consumer Review, Warranty Product dan Brand Trust Terhadap Purchase Decision Smartphone Xiaomi di Kabupaten Kebumen
}

\author{
Rezana Agustyan', Muhammad Baehaqi ${ }^{2}$ \\ ${ }^{1}$ Sekolah Tinggi Ilmu Ekonomi Putra Bangsa \\ ${ }^{2}$ Sekolah Tinggi Ilmu Ekonomi Putra Bangsa \\ Email : ezaagustyan19@gmail.com
}

\section{ARTICLE INFO}

Article History:

Received: March 5th 2020

Accepted: March $6^{\text {th }} 2020$

Published: April 30th 2020

Keywords:

Online Consumer Review, Warranty Product, Brand Trust, Purchase Decision.

\begin{abstract}
Penelitian ini bertujuan untuk menganalisis pengaruh online consumer review, warranty product dan brand trust terhadap purchase decision pada konsumen smartphone Xiaomi di Kabupaten Kebumen. Variabel bebas dalam penelitian ini adalah online consumer review, warranty product dan brand trust, sedangkan variabel terikatnya adalah purchase decision. Teknik dalam pengumpulan data dengan kuesioner menggunakan metode purposive sampling, sampel dalam penelitian ini sebanyak 100 responden. Hipotesis diuji dengan bantuan progam SPSS 23.00 for windows. Metode yang digunakan dalam penelitian ini adalah metode analisis regresi berganda. Hasil pengujian koefisien determinasi menunjukkan bahwa nilai Adjusted R2 sebesar 0,554 artinya 55,4\% variabel purchase decision dapat dipengaruhi oleh online consumer review, warranty dan brand trust dan $44,6 \%$ dipengaruhi variabel lain di luar model. Berdasarkan hasil analisis jalur dan uji $\mathrm{t}$ yang telah dilakukan dapat disimpulkan bahwa tingginya purchase decision dipengaruhi oleh online consumer review, warranty product dan brand trust.
\end{abstract}

\section{PENDAHULUAN}

Perkembangan teknologi informasi dan komunikasi di era modern sekarang ini telah membawa pengaruh kepada perubahan gaya hidup dan tingkat kebutuhan manusia yang terus meningkat. Pada zaman serba canggih seseorang membutuhkan komunikasi yang cepat dan mudah untuk menyampaikan dan menyebarkan informasi. Kebutuhan perangkat telekomunikasi seperti smartphone bagi penduduk berbagai negara di penjuru dunia merupakan hal yang wajib dan menjadi prioritas utama. Smartphone atau ponsel pintar digunakan tidak hanya sebagai media komunikasi namun semakin banyak kegunaannya. Mulai dari berbelanja, transaksi elektronik, media fotografi, bermain game dan lain sebagainya.

Menurut Rahmayani (2015) masyarakat Indonesia dengan jumlah lebih dari 250 juta jiwa sebagian besar merupakan pengguna aktif smartphone. Dari mulai anak-anak, remaja hingga orang tua mereka selalu bergantung pada smartphone. Ponsel pintar telah menjadi bagian hidup dan lifestyle yang sangat sulit terpisahkan dari masyarakat Indonesia. Gaya hidup masyarakat tersebut menjadi faktor meningkatnya permintaan terhadap smartphone. Kondisi 
seperti ini tentunya akan menarik minat setiap perusahaan smartphone untuk terus selalu melakukan inovasi pada seluruh produknya. Menurut penelitian yang dilakukan we are social perusahaan media asal Inggris yang bekerjasama dengan hootsuite, perkembangan teknologi informasi di Indonesia meningkat pesat dari hari ke hari dan dari tahun ke tahun. Hal ini dipengaruhi oleh berbagai macam faktor mulai dari perluasan area cakupan internet, peningkatan bandwidth internet, penggunaan teknologi internet dan komunikasi terbaru yang lebih cepat dan efisien, perkembangan ponsel pintar (smartphone), munculnya berbagai macam media sosial dan e-commerce, serta semakin banyaknya masyarakat yang paham dan aktif menggunakan internet.

Suatu perusahaan dalam mengembangkan produk tentu harus disesuaikan dengan kebutuhan dan selera konsumen, sehingga produk dapat bersaing dengan produk lainnya. Dalam pengembangan produk tentu harus melalui proses yang panjang dan perlu melakukan kajian mendalam hingga produk yang diluncurkan diminati pelanggan dan konsumen akan puas dengan produk yang ditawarkan tersebut. Perkembangan smartphone dengan desain dan berbagai fitur menarik serta harga yang terjangkau menjadi daya tarik tersendiri bagi konsumen, dan salah satu merek ternama yang menawarkan kelebihan tersebut yaitu smartphone merek Xiaomi. Xiaomi menjadi salah satu vendor yang sangat produktif di industri smartphone. Apalagi harga Xiaomi lebih murah dari pesaing dengan spesifikasi yang sama, tidak terkecuali untuk smartphone Xiaomi terbaru di 2019. Saat ini bisa dikatakan smartphone Xiaomi menjadi salah satu yang paling diminati di kalangan remaja sampai orang dewasa karena harganya terjangkau dengan fitur dan spesifikasi yang tinggi.

Perusahaan Xiaomi merupakan sebuah perusahaan besar yang berasal dari Tiongkok. Sebagai negara maju dengan berbagai macam teknologinya, Tiongkok hampir menguasai sebagian besar penjualan smartphone di Asia. Menurut Febriyandra (2018) pasar persaingan smartphone dari hari ke hari semakin sengit, banyak sekali vendor dan produsen smartphone yang satu sama lain tidak mau mengalah. Masing-masing berusaha mengembangkan produk andalannya agar dapat menarik perhatian konsumen dan laris di pasaran. Meskipun harga yang ditawarkan murah namun kualitas dan fitur smartphone Xiaomi ini dapat diandalkan dan dapat bersaing dengan produk-produk lain yang lebih dahulu meramaikan dunia telekomunikasi dunia seperti Samsung, Asus, Nokia, Apple dan merek lainnya.

Generasi muda merupakan pemakai terbanyak dari produk smartphone Xiaomi. Dikarenakan produk Xiaomi menawarkan spesifikasi yang mumpuni bagi para gamers dan dunia fotografi. Xiaomi menawarkan produk dari kapasitas memori yang kecil hingga besar menyesuaikan kebutuhan dari pengguna. Selain itu kualitas kamera smartphone Xiaomi juga memiliki kualitas gambar dengan hasil yang jernih. Dari tahun ke tahun jumlah pengguna smartphone Xiaomi terus mengalami peningkatan yang signifikan. Hal ini dapat dilihat pada tabel berikut:

Tabel 1, Data penjualan smartphone xiaomi di indonesia pada kuartal 2 tahun 2019

\begin{tabular}{cccc}
\hline No. & Merek Smartphone & Kuartal 1 tahun 2018 & Kuartal 2 tahun 2019 \\
\hline 1. & Samsung & $28 \%$ & $27 \%$ \\
2. & Xiaomi & $19 \%$ & $21 \%$ \\
3. & Oppo & $17 \%$ & $17 \%$ \\
4. & Vivo & $6 \%$ & $9 \%$ \\
5. & Realme & - & $8 \%$ \\
& Lainnya & $35 \%$ & $18 \%$ \\
\hline & Jumlah & $\mathbf{1 0 0} \%$ & $\mathbf{1 0 0} \%$ \\
\hline
\end{tabular}

Sumber: Data diolah, 2019 
Dari tabel 1 dapat ketahui penjualan smartphone Xiaomi pada kuartal kedua tahun 2019 menempati posisi kedua setelah produk dari perusahaan asal Korea yaitu Samsung. Trend penjualan dibandingkan dengan tahun 2018 pada kuartal yang sama juga mengalami peningkatan sebesar 2 persen. Angka 21 persen merupakan angka yang besar bagi penjualan smartphone Xiaomi di Indonesia. Dengan waktu yang tidak terlalu lama namun berhasil masuk dalam lima besar penjualan terbaik.

Strategi promosi penjualan Xiaomi pada mulanya memang sangat terlihat efisien. Perusahaan tidak menciptakan iklan di televisi dengan brand ambassador artis terkenal seperti beberapa pesaing lain yang berlomba-lomba menciptakan berbagai promosi di media elektronik. Memang anggaran biaya promosi membutuhkan dana yang banyak karena faktor inilah yang dibuat Xiaomi agar dapat menciptakan produk dengan harga yang murah dan kompetitif. Perusahaan Xiaomi dalam memasarkan produknya sama sekali tidak menggunakan media iklan berbayar seperti iklan televisi, iklan youtube, ataupun papan reklame. Hal ini menjadikan biaya promosi yang dilakukan perusahaan dapat digunakan untuk efisiensi produk yang menjadikan harga smartphone Xiaomi dapat bersaing dengan produk lainnya.

Promosi melalui mulut ke mulut (word of mouth) merupakan bentuk pemasaran yang telah lama ada dan efektif untuk mencari konsumen dan meningkatkan penjualan. Hal ini dirasa cukup mudah untuk dilakukan dan tidak membutuhkan biaya yang banyak. Strategi inilah yang dicoba Xiaomi dalam memasarkan produk melalui kepercayaan pelanggan dan loyalitas pelanggan. Sehingga akan mampu mengajak dan mempengaruhi orang lain untuk membeli ataupun menggunakan produk Xiaomi. Di era modern tentu peranan teknologi juga mengubah cara pemasaran menjadi electronic word of mouth. Belakangan ini keputusan pembelian konsumen juga dapat dipengaruhi oleh tulisan dan penilaian konsumen lain yang telah menggunakan suatu produk. Menurut Bagus (2019) istilah online consumer review merupakan konten buatan pengguna (user generated content) menjadi semakin penting pada era digital dimana ulasan konsumen independen menjadi hal kedua terpenting yang dapat mempengaruhi proses pemasaran suatu produk. Umumnya, orang membutuhkan rekomendasi untuk memutuskan membeli barang atau jasa. Sebanyak $70 \%$ orang mengandalkan review pelanggan yang beredar online. Konsumen semakin pintar dan semakin kebal dengan berbagai jenis iklan yang diberikan pemasar.

Pemberian layanan purna jual seperti garansi produk Xiaomi merupakan hal yang dipertimbangkan oleh beberapa konsumen sebelum membeli. Menurut Tjiptono (2008:16) perusahaan akan melakukan suatu aktivitas dengan memberikan layanan kepada pelanggan yang telah membeli produknya. Pelayanan yang diberikan oleh suatu perusahaan tidak selalu dapat memenuhi semua harapan para pelanggan. Persaingan usaha yang ketat antar perusahaan smartphone menciptakan berbagai keuntungan bagi konsumen. Selain berbagai keunggulan dan kualitas produk yang ditawarkan, layanan garansi produk yang lebih panjang dan proses klaim yang mudah juga menjadi prioritas utama perusahaan agar loyalitas konsumen tetap terjaga dengan baik. Proses klaim garansi yang mudah dengan layanan customer service yang ramah dan bersahabat menjadi kunci keberhasilan perusahaan dalam menciptakan kepercayaan pelanggan setia. Garansi adalah suatu kesepakatan kontraktual yang terkait dengan penjualan produk yang membutuhkan produsen untuk memperbaiki atau baik mengkompensasi kegagalan selama masa garansi (Shafayet, 2011). Memberikan garansi berarti mengeluarkan tambahan ongkos bagi produsen secara signifikan dari total penjualan. 
Kepercayaan terhadap merek yang dibangun Xiaomi terus mendapat tempat di hati konsumen. Kepercayaan yang didapat ini merupakan hasil kerja keras perusahaan dalam menciptakan produk yang unggul dan berkualitas serta layanan garansi produk Xiaomi yang ditawarkan, demi kepuasan dan kenyamanan layanan purna jual bagi konsumen. Perlahan citra smartphone Xiaomi terus naik sehingga produk asal Tiongkok ini tidak lagi dipandang sebelah mata oleh konsumen. Strategi penjualan produk Xiaomi memang cukup unik dibanding produk lain. Lewat progam flash sale melalui beberapa perusahaan $e$ commerce seperti Lazada, Blibli dan Shopee berhasil menarik minat hati puluhan ribu konsumen. Meskipun jumlah produk yang dijual saat flash sale sangatlah terbatas tidak menurunkan minat konsumen dalam berburu dan membeli produk yang mereka ingin dengan harga murah. Menurut Tjahyadi (2006:55) kepercayaan pelanggan pada merek (brand trust) didefinisikan sebagai keinginan pelanggan untuk bersandar pada sebuah merek dengan risiko-risiko yang dihadapi karena ekspektasi terhadap merek akan menyebabkan hasil yang positif.

\section{Kajian Teori dan Telaah Literatur}

\section{Purchase decision}

Kotler dan Keller (2013:184) berpendapat bahwa keputusan pembelian adalah suatu tahap dimana konsumen telah memiliki pilihan dan siap untuk melakukan pembelian atau pertukaran antara uang dan janji untuk membayar dengan hak kepemilikan atau penggunaan suatu barang atau jasa. Inti dari pengambilan keputusan konsumen adalah proses pengintegrasian yang mengkombinasikan pengetahuan untuk mengevaluasi dua atau lebih perilaku alternatif dan memilih salah satunya.

\section{Online consumer review}

Online consumer review merupakan salah satu jenis e-WOM yang memberikan informasi dan rekomendasi terkait produk dari perspektif konsumen, Jalilvand dan Samiei (2012). Menurut Almana dan Mirza (2013:23), online consumer review merupakan salah satu bentuk dari electronic word of mouth (e-WOM) yang terdiri dari analisis maupun komentar yang dihasilkan dan di posting oleh orang yang telah menghabiskan uang mereka untuk sebuah produk dan memang telah menggunakannya. Online consumer review dapat diartikan sebagai umpan balik dan rekomendasi dari konsumen yang berpengalaman atas produk dan jasa tertentu dan dapat menimbulkan minat beli pada konsumen potensial.

\section{Warranty product}

Garansi merupakan suatu kesepakatan kontraktual yang terkait dengan penjualan produk yang membutuhkan produsen untuk memperbaiki atau baik mengkompensasi kegagalan produk selama waktu tertentu yang dijanjikan (Shafayet, 2011). Garansi ada beberapa macam diantaranya yaitu garansi replacement yaitu produk yang diklaim akan diganti dengan item yang sama, garansi spare part yaitu pada produk yang diklaim spare part yang rusak, maka akan diganti dengan yang sama, dan garansi service. Pada umumnya penjual atau produsen akan mengganti atau memperbaiki produk yang mengalami kerusakan sesuai dengan masa yang berlaku (Mubarok, 2009:1).

\section{Brand trust}

Menurut Delgado (2003), brand trust (kepercayaan merek) adalah perasaan aman yang dimiliki oleh konsumen akibat dari interaksinya dengan sebuah merek, yang berdasarkan presepsi bahwa merek tersebut dapat diandalkan dan bertanggung jawab atas kepentingan dan keselamatan dari konsumen. Menurut Tjahjadi (2006:55) kepercayaan pelanggan pada 
merek (brand trust) didefinisikan sebagai keinginan pelanggan untuk bersandar pada sebuah merek dengan risiko-risiko yang dihadapi karena ekspetasi terhadap merek akan menyebabkan hasil yang positif.

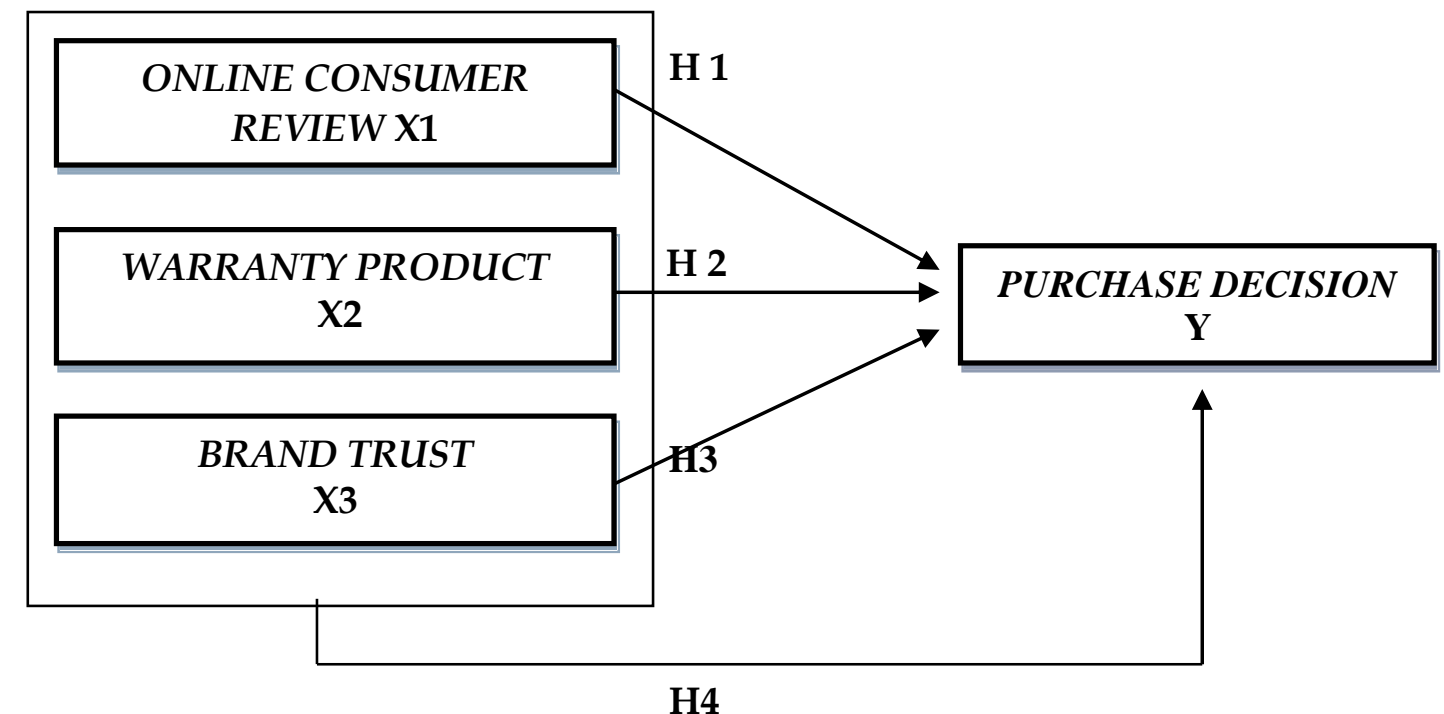

Gambar 1. Model penelitian

\section{Hipotesis :}

Berdasarkan kerangka penelitian diatas maka diperoleh hipotesis sebagai berikut :

$\mathbf{H}_{\mathbf{1}}$ : Terdapat pengaruh antara online consumer review dengan purchase decision pada konsumen smartphone Xiaomi di Kabupaten Kebumen.

$\mathbf{H}_{2}$ : Terdapat pengaruh antara warranty product dengan purchase decision pada konsumen smartphone Xiaomi di Kabupaten Kebumen.

$\mathbf{H}_{3}$ : Terdapat pengaruh antara brand trust dengan purchase decision pada konsumen smartphone Xiaomi di Kabupaten Kebumen.

$\mathbf{H}_{4}$ : Terdapat pengaruh antara online consumer review, warranty product dan brand trust dengan purchase decision pada konsumen smartphone Xiaomi di Kabupaten Kebumen.

\section{METODE PENELITIAN}

\section{Populasi dan sampel penelitian}

Populasi dalam penelitian ini adalah masyarakat di Kabupaten Kebumen yang pernah melakukan pembelian produk smartphone Xiaomi. Populasi dalam penelitian ini tidak diketaui jumlahnya. Jumlah sampel yang diambil dalam penelitian ini adalah 100 responden.

\section{Teknik pengambilan sampel}

Teknik pengambilan sampel yang digunakan dalam penelitian ini adalah non probability sampling yaitu teknik pengambilan sampel yang tidak memberikan peluang yang sama bagi setiap anggota populasi untuk dipilih menjadi sampel (Sugiyono, 2010:84). Teknik non probability sampling yang digunakan dalam penelitian ini yaitu purposive sampling yaitu teknik penentuan sampel dengan pertimbangan tertentu (Sugiyono, 2010:85). 


\section{Variabel dan pengukuran}

Penelitian ini menggunakan tiga variabel bebas dan satu variabel terikat. Variabel penelitian dalam jurnal ini adalah sebagai berikut:

a. Variabel bebas dalam penelitian ini yaitu:

$\mathrm{X} 1$ = Online Consumer Review

$\mathrm{X} 2=$ Warranty Product

$\mathrm{X} 3=$ Brand Trust

b. Variabel terikat dalam penelitian ini yaitu:

Y1 = Purchase Decision

\section{Uji kualitas data}

Uji validitas kuesioner penelitian ini menggunakan teknik pearson product moment, yaitu mengkorelasikan skor item dengan skor total dengan tingkat signifikasi 0,05. Selanjutnya dilakukan uji reliabilitas untuk mengukur kekonsistenan jawaban responden dengan pengujian menggunakan teknik statistik alpha cronbach's signifikasi sebesar $60 \%$.

\section{Metode analisis data}

Peneliti menggunakan SPSS versi 23.00 for windows yang digunakan untuk mengetahui bagaimana pengaruh online consumer review, warranty product dan brand trust terhadap purchase decision.

\section{Hasil dan Pembahasan}

Hasil analisis statistik dalam penelitian ini diperoleh dari jawaban kuesioner yang telah dibagikan kepada 100 responden, yaitu konsumen yang telah melakukan purchase decision smartphone Xiaomi di Kabupaten Kebumen. Berdasarkan data yang diperoleh dari hasil penelitian, maka dapat didefinisikan karakteristik responden sebagai berikut:

Tabel 2. Karakteristik responden berdasarkan jenis kelamin

\begin{tabular}{cccc}
\hline No & Keterangan & Frekuensi & Prosentase \\
\hline 1 & Laki-laki & 63 & $63 \%$ \\
2 & Perempuan & 37 & $37 \%$ \\
\hline & Total & $\mathbf{1 0 0}$ & $\mathbf{1 0 0} \%$ \\
\hline
\end{tabular}

Tabel 3. Karakteristik responden berdasarkan usia

\begin{tabular}{|c|c|c|c|}
\hline No & Keterangan & Frekuensi & Prosentase \\
\hline 1 & $17-25$ tahun & 53 & $53 \%$ \\
\hline 2 & 26-35 tahun & 36 & $36 \%$ \\
\hline 3 & 36-45 tahun & 7 & $7 \%$ \\
\hline 4 & 46-55 tahun & 4 & $4 \%$ \\
\hline & Total & 100 & $100 \%$ \\
\hline
\end{tabular}

Tabel 4.Karakteristik responden berdasarkan pekerjaan

\begin{tabular}{cccc}
\hline No & Keterangan & Frekuensi & Prosentase \\
\hline 1 & Mahasiswa/pelajar & 33 & $33 \%$ \\
2 & Karyawan Swasta & 41 & $41 \%$ \\
3 & Pegawai Negeri Sipil & 3 & $3 \%$ \\
4 & Wiraswasta & 17 & $17 \%$ \\
5 & Lain-lain & 6 & $6 \%$ \\
\hline & Total & $\mathbf{1 0 0}$ & $\mathbf{1 0 0} \%$ \\
\hline
\end{tabular}


Tabel 5. Karakteristik responden berdasarkan penghasilan / uang saku

\begin{tabular}{cccc}
\hline No & Keterangan & Frekuensi & Prosentase \\
\hline 1 & $<1$ jt & 31 & $31 \%$ \\
2 & 1 jt s/d 2jt & 30 & $30 \%$ \\
3 & 2 jt s/d 3 jt & 25 & $25 \%$ \\
4 & $>3$ jt & 14 & $14 \%$ \\
\hline & Total & $\mathbf{1 0 0}$ & $\mathbf{1 0 0} \%$ \\
\hline
\end{tabular}

\section{Uji validitas dan uji reliabilitas}

Hasil uji instrumen validitas dan reliabilitas menunjukkan bahwa semua item pengukuran dalam kuisioner dinyatakan valid dan reliabel. Hal ini didasarkan pada hasil uji validitas $r$ hitung untuk semua item pengukuran variabel $>r_{\text {tabel }}=0,198$ dengan tingkat signifikansi $<$ 0,05, sedangkan hasil uji instrumen reliabilitas menunjukkan bahwa nilai Alpha Cronbach dari keempat variabel $>0,6$.

\section{Uji normalitas}

Hasil uji asumsi normalitas menunjukkan bahwa data berdistribusi normal. Hal ini didasarkan pada gambar plot normalitas pada gambar dibawah ini yang menunjukkan bahwa data menyebar di sekitar/mendekati dan mengikuti garis diagonal.

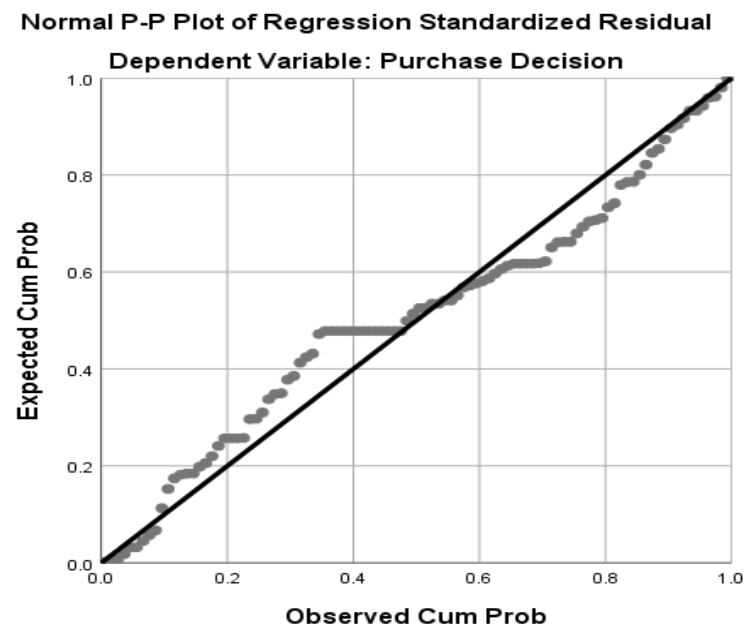

Gambar 2. Hasil uji normalitas

\section{Uji heterokedastisitas}

Hasil uji heterokesdastisitas menunjukkan bahwa data bebas heterokesdastisitas. Hal ini didasarkan pada hasil scatterplot dibawah ini dengan bulatan-bulatan kecil yang tidak memiliki suatu pola tertentu yang teratur (bergelombang, melebar, kemudian menyempit) dan tidak terdapat pola yang jelas, sehingga disimpulkan tidak terdapat gejala heterokesdastisitas. 


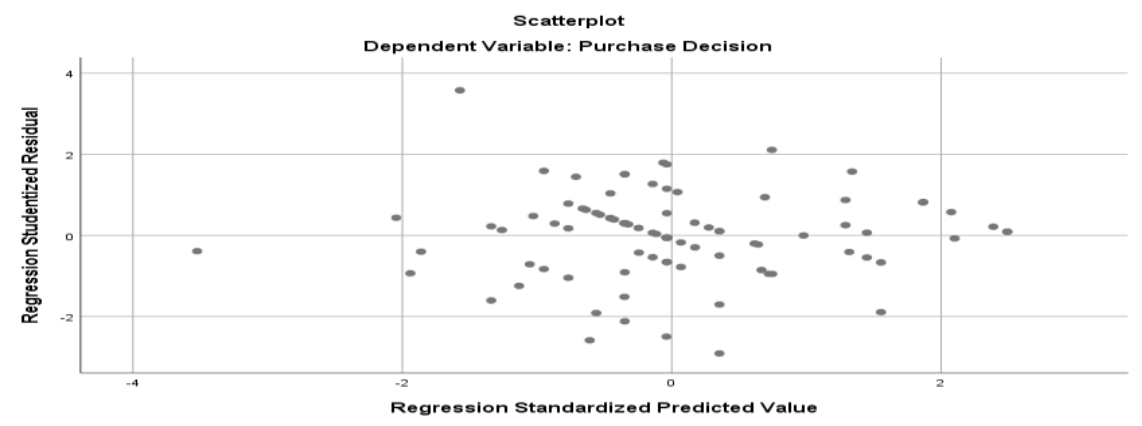

Gambar 3. Hasil uji heterokedastisitas

\section{Uji multikolinearitas}

Hasil uji multikolinieritas menunjukkan bahwa data bebas gejala multikolinieritas. Hal ini didasarkan pada hasil Collinearity Statistics di bawah ini yang menunjukkan bahwa nilai Tolerance semua variabel berada di atas $0,10(10 \%)$ dan nilai VIF semua variabel berada di bawah 10. Berdasarkan hasil uji normalitas, heterokesdastisitas, dan multikolinieritas maka dapat dikatakan bahwa tidak terdapat masalah asumsi klasik pada penelitian ini.

Tabel 6. Hasil uji multikolinearitas

\begin{tabular}{llcc}
\hline No & \multicolumn{2}{c}{ Collinearity } & Statistics \\
\hline & & Tolerance & VIF \\
\cline { 2 - 3 } 1 & Online Consumer Review & 0.687 & 1.456 \\
2 & Warranty Product & 0.880 & 1.137 \\
3 & Brand Trust & 0.722 & 1.385 \\
\hline
\end{tabular}

\section{Uji parsial (ujit)}

Uji t pada dasarnya menunjukkan seberapa jauh pengaruh satu variabel penjelas/ independen secara individual dalam menerangkan variasi variabel dependen (Ghozali, 2009).

Tabel 7. Hasil uji t

\begin{tabular}{cccccc}
\hline Variabel & Signifikan & $\boldsymbol{\alpha}$ & $\mathbf{t}_{\text {hitung }}$ & $\mathbf{t}_{\text {tabel }}$ & Keterangan \\
\hline $\mathrm{X} 1$ & 0.000 & 0.05 & 4.903 & 1.660 & Signifikan \\
$\mathrm{X} 2$ & 0.020 & 0.05 & 2.373 & 1.660 & Signifikan \\
$\mathrm{X} 3$ & 0.000 & 0.05 & 5.651 & 1.660 & Signifikan \\
\hline
\end{tabular}

\section{Uji simultan (ujif)}

Berdasarkan hasil Uji ANOVA atau bersama-sama diperoleh $F_{\text {hitung sebesar } 42.018>}$ $\mathrm{F}_{\text {tabel }} 2.70$ dengan tingkat signifikan $0,000<0,05$, maka dapat disimpulkan bahwa secara bersama-sama variabel online consumer review, warranty product dan brand trust berpengaruh signifikan terhadap purchase decision smartphone Xiaomi di Kabupaten Kebumen. 
Tabel 8. Hasil uji simultan (uji f)

\begin{tabular}{lrrrrr}
\hline \multicolumn{6}{c}{ ANOVA $^{\text {a }}$} \\
\hline & Sum of & \multicolumn{4}{c}{ Mean } \\
Model & Squares & $d f$ & Square & \multicolumn{1}{c}{$\boldsymbol{F}$} & \multicolumn{1}{c}{ Sig. } \\
Regression & 351.638 & 3 & 117.213 & 42.018 & $.000^{\mathrm{b}}$ \\
Residual & 267.802 & 96 & 2.790 & & \\
\hline Total & 619.440 & 99 & & & \\
\hline
\end{tabular}

\section{Pembahasan hipotesis}

\section{Variabel online consumer review}

Berdasarkan hasil analisis di atas di ketahui bahwa variabel online consumer review (X1)

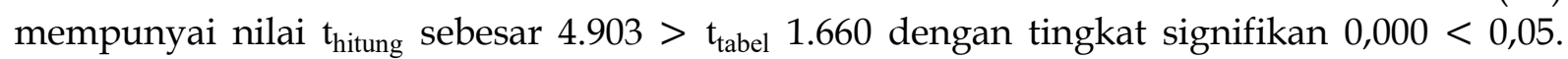
Hasil ini menyatakan bahwa variabel online consumer review mempunyai pengaruh yang signifikan terhadap purchase decision smartphone Xiaomi di Kabupaten Kebumen.

\section{Variabel warranty product}

Berdasarkan hasil analisis di atas di ketahui bahwa variabel warranty product (X2) mempunyai nilai $t_{\text {hitung }}$ sebesar $2.373>t_{\text {tabel }} 1,660$ dengan tingkat signifikan 0,020<0,05. Hasil ini menyatakan bahwa variabel warranty product mempunyai signifikan terhadap purchase decision smartphone Xiaomi di Kabupaten Kebumen.

\section{Variabel brand trust}

Berdasarkan hasil analisis di atas di ketahui bahwa variabel brand trust (X3) mempunyai nilai $t_{\text {hitung }}$ sebesar $5.651>t_{\text {tabel }} 1,660$ dengan tingkat signifikan 0,000 $<0,05$. Hasil ini menyatakan bahwa variabel brand trust mempunyai signifikan terhadap purchase decision smartphone Xiaomi di Kabupaten Kebumen.

\section{Penutup dan Saran}

\section{Simpulan}

Berdasarkan hasil pembahasan analisis data melalui pembuktian terhadap hipotesis dari permasalahan yang diangkat mengenai faktor-fakor yang mempengaruhi purchase decision smartphone Xiaomi di Kabupaten Kebumen. Maka diperoleh kesimpulan sebagai berikut: 1.) Pengujian hipotesis pertama dilakukan untuk mengetahui pengaruh online consumer review terhadap purchase decision. Hasil dari pengujian ini menunjukkan bahwa online consumer review berpengaruh secara signifikan terhadap purchase decision dengan hasil uji $\mathrm{t}$ sebesar 4.903 dengan tingkat signifikan 0,000 $<0,05$. Hasil penelitian ini sejalan dengan penelitian yang dilakukan oleh Korina Tasya Kamila, Suharyono dan Inggang Perwangsa Nuralam (2019) yang menyatakan bahwa online consumer review berpengaruh secara signifikan terhadap purchase decision, 2.) Pengujian hipotesis kedua dilakukan untuk mengetahui pengaruh warranty product terhadap purchase decision. Hasil dari pengujian ini menunjukkan bahwa warranty product berpengaruh secara signifikan terhadap purchase decision dengan hasil uji $\mathrm{t}$ sebesar 2.373 dengan tingkat signifikan $0,020<0,05$. Hasil penelitian ini sejalan dengan penelitian yang dilakukan oleh Putu Agus Wira Putra dan Ni Ketut Seminari (2014) yang menyatakan bahwa warranty product berpengaruh secara signifikan terhadap purchase decision, 3.) Pengujian hipotesis ketiga dilakukan untuk mengetahui pengaruh brand trust terhadap purchase decision. Hasil dari pengujian ini menunjukkan bahwa brand trust berpengaruh seacara signifikan terhadap purchase decision dengan hasil uji t sebesar 5.651 dengan tingkat signifikan $0,00<0,05$. Hasil penelitian ini sejalan dengan penelitian yang dilakukan oleh Muhammad Abimanyu Ridwan (2018) yang menyatakan bahwa brand trust 
berpengaruh secara signifikan terhadap purchase decision, 4.) Berdasarkan hasil uji $\mathrm{F}$ dalam penelitian ini diperoleh nilai $\mathrm{F}_{\text {hitung }}$ sebesar $42.018>\mathrm{F}_{\text {tabel }}$ 2,70 dengan tingkat signifikan sebesar $0,000<0,05$. Hal ini membuktikan bahwa variabel online consumer review, warranty product dan brand trust secara bersama-sama berpengaruh signifikan terhadap purchase decision. Sedangkan berdasarkan hasil uji $\mathrm{R}^{2}$ (Koefisien Determinasi) diperoleh nilai 0.554 sehingga dapat disimpulkan bahwa besarnya variabel independent dalam mempengaruhi variabel dependent sebesar 55,4\% dan sisanya sebesar $44,6 \%$ dijelaskan oleh variabel lain yang tidak disebutkan dalam penelitian ini.

\section{Saran}

\section{Bagi perusahaan}

Perusahaan Xiaomi sebaiknya terus melakukan perbaikan dalam strategi periklanan karena semakin ketat persaingan bisnis yang dilakukan perusahaan lain saat ini. Peningkatan pelayanan purna jual dalam hal pemberian garansi juga akan meningkatkan kepercayaan dan loyalitas pelanggan bagi keberlangsungan perusahaan. Pengaruh yang kuat dimiliki oleh Brand Trust dalam mempengaruhi keputusan pembelian mengindikasikan kepercayaan konsumen terhadap merek Xiaomi terus meningkat. Oleh karena itu perusahaan diharapkan untuk selalu meningkatkan kualitas produk maupun pengingkatan layanan yang ditawarkan.

\section{Bagi peneliti selanjutnya}

Model menunjukan dapat menjelaskan 55,4\% informasi yang terkandung dalam data. Mengingat pengaruh variabel diluar penelitian ini cukup tinggi yaitu $44,6 \%$ maka penelitian selanjutnya diharapkan dapat mengembangkan penelitian dengan meneliti variabel lain yang ada di luar penelitian ini atau mengkombinasikan variabel lain seperti kualitas produk dan persepsi harga.

\section{Referensi}

Al Mana, A. M., \& Mirza, A. A. (2013). The impact of electronic word of mouth on consumers' purchasing decisions. International Journal of Computer Applications, 82(9).

Bagus, A. (2019). Pentingnya Review Pelanggan. Diambil dari https://astahub.id/pentingnyareview-pelanggan/ diakses tanggal 8 oktober 2019.

Delgado-Ballester, E., \& Munuera-Alemán, J. L. (2001). Brand trust in the context of consumer loyalty. European Journal of marketing, 35(11/12), 1238-1258.

Febriyandra, D. (2018). Alasan HP Xiaomi Murah. Diambil dari https://www.mastekno.com/id/alasan-hp-xiaomi-murah/ diakses tanggal 2 oktober 2019.

Jalilvand, M. R., \& Samiei, N. (2012). The effect of electronic word of mouth on brand image and purchase intention. Marketing Intelligence E Planning, 30(4), 460-476.

Kamila, K. T., Suharyono, S., \& Nuralam, I. P. (2019). Pengaruh Online Consumer Review Terhadap Keputusan Pembelian (Survei pada Mahasiswa Universitas Brawijaya TA 2015/2016-2018/2019 yang Pernah Membeli dan Menggunakan Xiaomi Smartphone). Jurnal Administrasi Bisnis, 72(1), 202-211.

Kotler, P. (2008). Manajemen Pemasaran. Edisi 12 Jilid 2. Indeks: Jakarta.

Kotler, P., \& Keller, K. L. (2009). Manajemen Pemasara, Edisi ke-13, Jilid I. Jakarta: Erlangga. 
Mubarok, Z. (2009). Tinjauan Hukum Islam Terhadap Garansi Lifetime Hardware Komputer. Skripsi. Universitas Islam Negeri Sunan Kalijaga Yogyakarta.

Putra, P. A. W., \& Seminari, N. K. (2014). Pengaruh fitur, layanan pelengkap dan garansi terhadap keputusan pembelian handphone (Studi Kasus pada Mahasiswa S1 Fakultas Ekonomi dan Bisnis Universitas Udayana Denpasar). E-Jurnal Manajemen.

Rahmayani, I. (2015). Indonesia Raksasa Teknologi Digital Asia. Diambil dari https:// kominfo.go.id/content/detail/6095/indonesia-raksasa-teknologi-digitalasia/0/sorotan_media diakses tanggal 30 september 2019.

Ridwan, M. A. (2018). Analisis Pengaruh Gaya Hidup dan Kepercayaan Merek Terhadap Keputusan Handphone. doctoral disertation. Surakarta : Universitas Muhammadiyah Surakarta.

Sugiyono. (2010). Metode Penelitian Pendidikan Pendekatan Kuantitatif, kualitatif, dan RED. Bandung : Alfabeta.

Tjahyadi, R. A. (2006). Brand Trust dalam Konteks Loyalitas Merek: Peran Karakteristik Merek, Krakteristik Perusahaan, dan Karakteristik Hubungan Pelanggan-Merek. Jurnal Manajemen Maranatha, 6(1), 65-78.

Tjiptono, F. (2008). Strategi Pemasaran. Edisi 3. Yogyakarta : Andi.

Ullah, G. M., \& Islam, M. (2011). Effects of warranty on purchase decision of electronic products: an empirical research from the perspective of Bangladesh. Industrial Engineering Letters, 1(1), 11-25. 